\title{
Group B streptococcus tricuspid endocarditis presenting with arthralgia in a postpartum woman: a case report
}

\author{
Paul Vincent", Russell Davis and Debashis Roy
}

\begin{abstract}
Introduction: Infective endocarditis presenting with arthralgia is rare. Group B streptococcus tricuspid endocarditis as a postpartum complication is even rarer. The present case is an example of both.

Case presentation: We report the case of a 30-year-old Caucasian woman who presented with painful swelling of her wrists and ankles.

Conclusion: Even when the clinical presentation of systemic inflammation is more suggestive of a primary rheumatological disorder, it is important to remember that bacterial infection can also present in this manner. Group B streptococcus tricuspid valve endocarditis is a rare, but recognized, postpartum complication.
\end{abstract}

\section{Introduction}

Many diseases feature multisystem involvement. Diagnosing these diseases correctly is challenging enough. However, a particular conundrum occurs when the atypical presentation of one condition happens to fit the diagnostic criteria for a different condition. If the two conditions have completely different managements, it becomes a matter of life and death. Such a case is described here.

\section{Case presentation}

A 30-year-old Caucasian woman presented to our Accident and Emergency department with immobility due to back pain. She reported a 10-day history of lumbar back pain, which started three days after giving birth. The pain was worse with movement and radiated down her legs. After seven days, the pain spread to involve her wrists, elbows, knees and ankles.

Our patient's past medical history included only recent childbirth. Two weeks previously, she had given birth at 40 weeks to a healthy baby boy. Other than some light bleeding in the first trimester, there had been no antenatal symptoms or abnormalities on routine blood work or scans. She had no history of unexplained fever,

\footnotetext{
* Correspondence: paolodivincenzi@doctors.org.uk

Sandwell General Hospital, Lyndon West Bromwich, West Midlands B71 4HJ, UK
}

sweats, vaginal discharge or pelvic tenderness. The delivery was unremarkable other than having required an episiotomy just before delivery because of a seconddegree tear. One day after the delivery, our patient had complained of dysuria and was treated with trimethoprim for a urinary tract infection. The baby had not required hospitalization after delivery. He was fit and well at the time of our patient's admission. There was no previous or family history of any autoimmune conditions, specifically primary arthropathies.

Initial observations revealed mild tachycardia only (heart rate, 107 beats per minute). No fever was detected. A clinical examination revealed warm, red, swollen wrists, forearms and shins and stiff elbows, ankles and knees with restricted ranges of motion. Heart sounds I and II were present with no additional sounds. Her breath sounds were normal and vesicular without any crepitations or bronchial breathing. An abdominal examination was unremarkable. A vaginal examination revealed a mildly tender cervix, but no vaginal discharge. Results of initial investigations included a platelet count of $13 \times 10^{9} / \mathrm{L}$ (normal range: $150 \times 10^{9}$ to $450 \times 10^{9} / \mathrm{L}$ ), Creactive protein of $312 \mathrm{mg} / \mathrm{L}$ (normal range: $<5 \mathrm{mg} / \mathrm{L}$ ), albumin of $22 \mathrm{~g} / \mathrm{L}$ (normal range: 35 to $50 \mathrm{~g} / \mathrm{L}$ ), urea of $20 \mathrm{mmol} / \mathrm{L}$ (normal range: 2.5 to $6.7 \mathrm{mmol} / \mathrm{L}$ ) and creatinine of $100 \mu \mathrm{mol} / \mathrm{L}$ (normal range: 44 to $133 \mu \mathrm{mol} / \mathrm{L}$ ). A urine dipstick was positive for blood, protein and leukocytes and 
negative for nitrites. A urine culture from two weeks before had grown Escherichia coli that was sensitive to nitrofurantoin and trimethoprim. Results of other initial investigations are shown in Table 1.

In view of the unexplained inflammation with renal, joint and hematological involvement, a provisional diagnosis of systemic lupus erythematosus (SLE) was made. Differential diagnoses included occult sepsis (puerperal or urinary being considered most likely), HELLP syndrome (hemolysis, elevated liver enzymes and low platelet count), and a primary autoimmune nephropathy.

Our patient was started empirically on broad-spectrum intravenous antibiotics (gentamicin and amoxicillin with clavulanic acid) while confirmatory investigation results were pending.

On the second day of admission, our patient's level of consciousness decreased to Glasgow Coma Scale (GCS) 10, with delirium and agitation. This was considered to possibly represent either neurological involvement in SLE or delirium due to sepsis. Antibiotic coverage was changed to intravenous ceftriaxone and acyclovir. Bacterial meningitis, viral encephalitis and thrombotic thrombocytopenic purpura were added to the differential diagnoses.

An urgent computed tomography scan of our patient's head was performed, which showed no abnormalities. Our patient was transferred to our Critical Care department for observation of her consciousness level, which returned to GCS 15 over the course of several hours. A lumbar puncture was considered, but was not performed because of persisting profound thrombocytopenia.

By the end of day 3 after admission, a diagnosis had still not been made. There was no antibody evidence of SLE or any other autoimmune process. Blood films and bone marrow aspiration had shown no evidence of hemolysis or malignancy, two sets of blood cultures and a vaginal swab had been negative, and an abdominal ultrasound had failed to reveal a source of infection. Blood films showed toxic granulation of neutrophils, consistent with systemic sepsis. A complete list of investigations up to this point can be seen in Table 2 .

Although still without a diagnosis, the bone marrow aspirate and blood film results and low reticulocyte count were more consistent with severe sepsis causing bone marrow suppression than an autoimmune hemolytic process. Along with the negative autoimmune tests, SLE was now considered less likely. The significance of the borderline positive mycoplasma serology was doubtful. Doxycycline was added to the antibiotic regimen, and plans were made to repeat the titers in one to two weeks.

On the evening of day 3 after admission, our patient unexpectedly developed sinus bradycardia at a rate of 35 beats per minute. A transthoracic echocardiogram revealed a large echogenic mass attached to the anterior leaflet of her tricuspid valve that was consistent with a vegetation or thrombus, moderate tricuspid regurgitation, a mildly dilated right heart with reduced right ventricular function, and mild left ventricular systolic impairment (Figure 1).

Our patient was re-examined by two cardiologists and a cardiothoracic surgeon for clinical evidence of endocarditis. No murmur was identified. There was some speculation as to whether or not there were two splinter hemorrhages on the left thumbnail, but this was not considered definitive.

A computed tomographic pulmonary angiogram was performed to look for septic emboli and showed widespread

Table 1 Results of initial investigations

\begin{tabular}{|c|c|c|c|}
\hline $\begin{array}{l}\text { Haemoglobin } \\
\text { (11.5-15 grams/decilitre) }\end{array}$ & 9.9 & $\begin{array}{l}\text { Albumin } \\
\text { (35-50 grams/Litre) }\end{array}$ & 22 \\
\hline $\begin{array}{l}\text { White cell count } \\
\left(4-1110^{9} / \text { Litre }\right)\end{array}$ & 5.9 & $\begin{array}{l}\text { Bilirubin } \\
\text { (<21 micromoles/Litre) }\end{array}$ & 33 \\
\hline $\begin{array}{l}\text { Platelets } \\
\left(150-45010^{9} / \text { Litre }\right)\end{array}$ & 13 & $\begin{array}{l}\text { Alanine Aminotransferase } \\
\text { ( }<41 \text { international units/Litre) }\end{array}$ & 32 \\
\hline $\begin{array}{l}\text { Mean Cell Volume } \\
\text { (79-99 femtolitres) }\end{array}$ & 85.7 & $\begin{array}{l}\text { Alkaline Phosphatase } \\
\text { (20-130 international units/Litre) }\end{array}$ & 254 \\
\hline $\begin{array}{l}\text { International Normalised } \\
\text { Ratio }\end{array}$ & 1.27 & $\begin{array}{l}\text { C-Reactive Protein } \\
\text { ( }<5 \text { milligrams/Litre) }\end{array}$ & 312 \\
\hline $\begin{array}{l}\text { Urea } \\
\text { (2.5-6.7 millimoles/L) }\end{array}$ & 20 & $\begin{array}{l}\text { Erythrocyte Sedimentation Rate } \\
\text { (1-12 millimetres/hour) }\end{array}$ & 95 \\
\hline $\begin{array}{l}\text { Creatinine } \\
\text { (44-133 millimoles/Litre) }\end{array}$ & 100 & & \\
\hline $\begin{array}{l}\text { Sodium } \\
\text { (135-145 millimoles/Litre) }\end{array}$ & 137 & Electrocardiogram & $\begin{array}{c}\text { Sinus } \\
\text { tachycardia }\end{array}$ \\
\hline $\begin{array}{l}\text { Potassium } \\
\text { (3.5-5 millimoles/Litre) }\end{array}$ & 5.2 & Chest X Ray & Normal \\
\hline
\end{tabular}

Routine investigations upon admission showed marked systemic inflammation, renal failure, thrombocytopenia and hypoalbuminemia. 
Table 2 Further investigations available by the third day of admission

\begin{tabular}{|c|c|c|c|}
\hline \multirow{2}{*}{$\frac{\text { Microbiology }}{\text { Mid Stream Urine }}$} & \multirow[b]{2}{*}{ No organisms } & \multicolumn{2}{|l|}{ Haematology } \\
\hline & & Blood film & $\begin{array}{l}\text { Toxic granulation of } \\
\text { neutrophils. } \\
\text { No schistocytes seen }\end{array}$ \\
\hline High vaginal swab & No growth & $\begin{array}{l}\text { Dilute Russell Viper venom test } \\
(<1.2)\end{array}$ & 1.99 \\
\hline cervical chlamydia screen & Negative & $\begin{array}{l}\text { Fibrinogen } \\
\text { (2-6 grams/Litre) }\end{array}$ & 9.1 \\
\hline Syphilis antibodies & Negative & $\begin{array}{l}\text { D-dimer } \\
(<0.5 \text { microgram Fibrinogen } \\
\text { Equivalent Units } / \mathrm{ml})\end{array}$ & 18.22 \\
\hline Antistrepsolysin $\mathrm{O}$ titres & Negative & $\begin{array}{l}\text { C3 } \\
\text { (0.75-1.75 grams/Litre) }\end{array}$ & 1.36 \\
\hline Parvovirus lgM & Negative & $\begin{array}{l}\text { C4 } \\
\text { (0.14-0.54 grams/Litre) }\end{array}$ & 0.07 \\
\hline Mycoplasma antibodies & 1:320 milli-International & Bone marrow aspirate & Reactive and fibrotic \\
\hline$(<1: 320 \mathrm{mlU} / \mathrm{ml})$ & Units per millilitre & & No malignant cells \\
\hline Blood cultures $\times 3$ & No growth & $\begin{array}{l}\text { Ferritin } \\
\text { (10-300 nanograms/millilitre) }\end{array}$ & 738 \\
\hline $\begin{array}{l}\text { Methicillin Resistant Staphylococcus } \\
\text { Aureus nose and groin swabs }\end{array}$ & Negative & Direct Coombs test & $\begin{array}{l}\text { Negative for anti lgG } \\
\text { Weakly positive for anti } \\
\text { C3b/d }\end{array}$ \\
\hline Human Immunodeficiency Virus $1+2$ & Negative & & \\
\hline $\begin{array}{l}\text { Herpes Simplex Virus Polymerase } \\
\text { Chain Reaction } 1+2\end{array}$ & Negative & & \\
\hline Immunology & & Biochemistry & \\
\hline Anti Nuclear Antibody & Negative & $\begin{array}{l}\text { Total protein } \\
\text { (60-80 grams/Litre) }\end{array}$ & 46 \\
\hline Anti Neutrophil Cytoplasmic Antibody & Negative & $\begin{array}{l}\text { CK } \\
(<167 \text { International Units/Litre })\end{array}$ & 316 \\
\hline $\begin{array}{l}\text { Anti double-stranded deoxyribonucleic } \\
\text { acid (DNA) }\end{array}$ & Negative & $\begin{array}{l}\text { Urine albumin/Creatinine ratio } \\
(<2.26 \text { milligrams/millimole) }\end{array}$ & 4.87 \\
\hline $\begin{array}{l}\text { Rheumatoid factor } \\
(<20 \text { International Units/millilitre) }\end{array}$ & $\begin{array}{l}<11 \text { International Units/ } \\
\text { millilitre }\end{array}$ & $\begin{array}{l}\text { LDH } \\
(<225 \text { International Units/Litre) }\end{array}$ & 314 \\
\hline $\lg G$ & 10.3 & & \\
\hline \multicolumn{4}{|l|}{ (5.3-16.5 grams/Litre) } \\
\hline $\lg A$ & 2.26 & Radiology & \\
\hline \multicolumn{4}{|l|}{ (0.8-4 grams/Litre) } \\
\hline $\lg M$ & 3.08 & Computed Tomography head & Normal \\
\hline \multicolumn{4}{|l|}{ (0.5-2.5 grams/Litre) } \\
\hline Urine Bence Jones protein & Negative & Ultrasound abdomen & Normal \\
\hline Cardiolipin lgG & 2.3 & Computed Tomography abdomen & Distended uterus, in keeping \\
\hline ( $<10$ anti-lgG phospholipid units/millilitre) & & & $\begin{array}{l}\text { with post-partum changes; } \\
\text { otherwise normal. }\end{array}$ \\
\hline
\end{tabular}

Although a diagnosis was still lacking, results at this time pointed more toward severe sepsis than any other of our differentials.

bilateral subsegmental emboli across both lungs. Her antibiotic coverage was changed again to daily gentamicin, ceftriaxone and vancomycin. A plan was made to treat with two weeks of intravenous antibiotics with the current regimen, then to repeat the echocardiogram.

After two weeks, a repeat echocardiogram showed no significant change, nor was there inflammatory resolution: her C-reactive protein level, after initially decreasing, remained consistent at $>300 \mathrm{mg} / \mathrm{L}$ (normal range: $<5 \mathrm{mg} / \mathrm{L}$ ). Our patient's arthralgia also failed to improve. Repeat mycoplasma serology failed to show rising titers, confirming suspicion that the borderline positive result was not significant. Table 3 shows her blood test results two weeks after admission. 


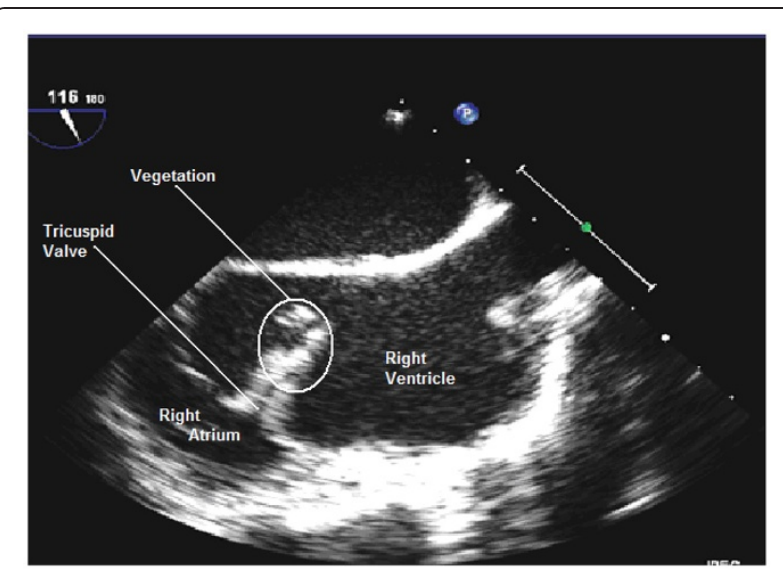

Figure 1 Transesophageal echocardiogram image of tricuspid vegetation. After initial imaging of the vegetation by a transthoracic echocardiogram, a transesophageal echocardiogram was performed to rule out an associated root abscess and in anticipation of a preoperative work-up.

For definitive treatment, our patient was scheduled for tricuspid valve removal and replacement. Sixteen days after her initial admission, she was transferred to a specialist cardiothoracic center. Operative findings included pericardial effusion, severe right atrial dilatation, a volume-loaded right ventricle, and a large vegetation on the anterior and posterior leaflets of her tricuspid valve.

Table 3 Blood results two weeks after admission

\begin{tabular}{lc}
\hline Haemoglobin (11.5-15 grams/decilitre) & 7.7 \\
Platelets (150-450 109/Litre ) & 379 \\
Mean Cell Volume (79-99 femtolitres) & 89.2 \\
White cell count (4-11 109/Litre) & 4.6 \\
Albumin (35-50 g/Litre) & 21 \\
Bilirubin (<21 micromoles/Litre) & 27 \\
Alkaline Phosphatase (20-130 & 217 \\
International Units/Litre) & \\
Alanine Aminotransferase (<41 & 22 \\
International Units/Litre) & 10.2 \\
Urea (2.5-6.7 millimoles/Litre) & 78 \\
Creatinine (44-133 micromoles/Litre) & 139 \\
Sodium (135-145 millimoles/Litre) & 4.8 \\
Potassium (3.5-5 millimoles/Litre) & 349 \\
C-Reactive Protein (<5 milligrams/Litre) & No growth \\
Blood cultures (5 sets sent in total) & Day 2 of admission 1:320 \\
Mycoplasma serology (<1:320 & \\
milli-International & Day 9 of admission 1:320 \\
Units per millilitre) & Day 15 of admission 1:320 \\
&
\end{tabular}

Although the patient's profound thrombocytopenia had resolved, antibiotic therapy had failed to affect the increased C-reactive protein levels or hypoalbuminemia.
The mural leaflet was spared. Her tricuspid valve was removed, and a $27 \mathrm{~mm}$ biological valve was inserted.

A postoperative echocardiogram showed good valve function with a small amount of paravalvular leakage. Pericardial fluid and vegetation microscopy, sensitivity and culture failed to identify a pathogen. A sample of the vegetation was sent to a reference laboratory. The pathogen was eventually identified by $16 \mathrm{~S}$ ribosomal deoxyribonucleic acid (DNA) sequence analysis as Streptococcus Lancefield Group B (GBS; Streptococcus agalactiae).

The source remained unclear; there was no clinical evidence of chorioamnionitis or infection of the episiotomy incision. Asymptomatic infection at either of these sites could have caused hematogenous spread. Another possibility is transient bacteremia from superficial colonization with Group B Streptococcus, without a primary local infection. Antenatal screening for Group B Streptococcus colonization is not routine in the UK and was not performed in our patient.

Our patient was continued on the antibiotic regimen of gentamicin, vancomycin and ceftriaxone for an additional 22 days. After this period, all inflammatory markers had normalized. Our patient's original polyarthritis finally resolved. At the three-month follow-up, all abnormal blood parameters had returned to normal levels (Table 4). Our patient was pain-free with a normal exercise tolerance.

\section{Discussion}

This case is a reminder of the heterogeneity of conditions that can present with musculoskeletal symptoms. Practically any infectious process may cause a reactive

Table 4 Blood results three months post-valve replacement

\begin{tabular}{lc}
\hline Haemoglobin (11.5-15 grams/decilitre) & 15.8 \\
White cell count (4-11 10\%/Litre) & 6.7 \\
Platelets (150-450 109/Litre ) & 211 \\
Mean Cell Volume (79-99 femtolitres) & 87.4 \\
Albumin (35-50 g/Litre) & 52 \\
Bilirubin (<21 micromoles/Litre) & 6 \\
Alanine Aminotransferas (<41 International Units/Litre) & 29 \\
Alkaline Phosphatase (20-130 International Units/Litre) & 102 \\
Urea (2.5-6.7 millimoles/Litre) & 5 \\
Creatinine (44-133 micromoles/Litre) & 66 \\
Sodium (135-145 millimoles/Litre) & 143 \\
Potassium (3.5-5 millimoles/Litre) & 3.9 \\
C-Reactive Protein (<5 milligrams/Litre) & $<5$ \\
Dilute Russell Viper venom test (<1.2) & 1.14 \\
\hline
\end{tabular}

Results at three months showed complete resolution of abnormal results. 
polyarthritis, although this is more common with some organisms (for example, Chlamydia) than others.

It is important to remember that it is not uncommon for malignancies to present with musculoskeletal symptoms. This may occur by various mechanisms, including bone pain from metastases or lytic lesions, paraneoplastic polyarthritis (mostly seen in breast, lung and renal cell carcinoma), or polymyositis and/or dermatomyositis.

This case also highlights the need for a systematic approach to diagnose inflammation of an unknown origin. A useful approach is to follow that of pyrexia of unknown origin [1], the main diagnosis categories of which are infection, autoimmune disease and malignancy.

Infective endocarditis is a relatively uncommon condition that, if undiagnosed, leads to serious morbidity and mortality [2]. There are many documented instances of infective endocarditis presenting in an atypical fashion $[3,4]$. This case presented a particularly difficult diagnostic challenge. At no point in this patient's admission did she display even a low-grade fever (the most sensitive clinical symptom or sign [5]), an increased neutrophil count, a murmur or clinical signs of heart failure.

Furthermore, our patient met the diagnostic criteria for SLE, displaying four of the eleven diagnostic features: non-erosive arthritis, hematological manifestation (thrombocytopenia), renal involvement (proteinuria) and neurological involvement (acute confusional state).

GBS endocarditis is associated with pregnancy and older patients with comorbidities. Our patient showed typical complications of mild systolic dysfunction of both ventricles and requirement of valve replacement.

GBS is a common pathogen in puerperal sepsis. A correlation between pregnancy and GBS tricuspid endocarditis is therefore conspicuous by its absence: a literature review revealed only seven cases of pregnancy-associated GBS tricuspid endocarditis [6].

Because GBS screening is not routinely performed in the UK, our patient was not offered antenatal screening. Because of the rarity of GBS endocarditis, it is doubtful whether a positive result would have given an indication of the diagnosis. A debate of the benefits of antenatal GBS screening is beyond the scope of this case report. GBS endocarditis is certainly not a common enough postpartum complication to be used as an argument in favor of screening.

\section{Conclusion}

We report an atypical presentation of infective endocarditis presenting with features of an inflammatory polyarthropathy. This case highlights the importance of considering an empirical investigation for a bacterial infection in any patient with unexplained biochemical evidence of inflammation, even in the presence of clinical features suggesting a primary rheumatological disorder.

\section{Consent}

Written informed consent was obtained from the patient for publication of this case report and accompanying images. A copy of the written consent is available for review by the Editor-in-Chief of this journal.

\section{Competing interests}

The authors declare that they have no competing interests.

\section{Authors' contributions}

PV collated clinical details and investigation results of the case and was the primary author of the manuscript. RD performed imaging of the tricuspid valve, chose a still image for submission, and was a major contributor to the literature review. DR was a major contributor in establishing the narrative of the case presentation. All authors read and approved the final manuscript.

Received: 5 December 2011 Accepted: 1 May 2012

Published: 14 August 2012

\section{References}

1. Vanderschueren S, Del Biondo E, Ruttens D, Van Boxelaer I, Wauters E, Knockaert DD: Inflammation of unknown origin versus fever of unknown origin - two of a kind. Eur J Intern Med 2009, 20(4):415-418.

2. Paterick TE, Paterick TJ, Nishimura RA, Steckelberg JM: Complexity and subtlety of infective endocarditis. Mayo Clin Proc 2007, 82(5):615-621.

3. Pande A, Ghosh B, Pain S, Karmakar RN, Ghosh A, Saha S: An unusual presentation of staphylococcal tricuspid valve infective endocarditis. NZ Med J 2010, 123(1311):73-76.

4. Lassmann B, Khan A, Baddour LM, Mueller PS: Dysphagia as an unusual presentation of infective endocarditis. Scand J Infect Dis 2007, 39(5): 460-463.

5. Mylonakis E, Calderwood SB: Infective endocarditis in adults. New Eng J Med 2001, 345(18):1318-1330.

6. Shimoni Z, Ben David M, Niven MJ: Group B streptococcal tricuspid valve endocarditis. Isr Med Assoc J 2006, 8:883-884.

doi:10.1186/1752-1947-6-242

Cite this article as: Vincent et al:: Group B streptococcus tricuspid endocarditis presenting with arthralgia in a postpartum woman: a case report. Journal of Medical Case Reports 2012 6:242.

\section{Submit your next manuscript to BioMed Central and take full advantage of:}

- Convenient online submission

- Thorough peer review

- No space constraints or color figure charges

- Immediate publication on acceptance

- Inclusion in PubMed, CAS, Scopus and Google Scholar

- Research which is freely available for redistribution 